\title{
Effect of Complete Feed Feeding Level and Morning Glory on Growing Pig Performance
}

\author{
Samorn Sreng1*, Sath Keo², J. M. DeRouchey³, M. D. Tokach³, Lyda Hok ${ }^{4,5}$, J. L. Vipham³ \\ ${ }^{1}$ Faculty of Animal Science, Royal University of Agriculture, Phnom Penh, Cambodia \\ ${ }^{2}$ Faculty of Veterinary Medicine, Royal University of Agriculture, Phnom Penh, Cambodia \\ ${ }^{3}$ Department of Animal Sciences and Industry, Kansas State University, Manhattan, USA \\ ${ }^{4}$ Faculty of Agronomy, Royal University of Agriculture, Phnom Penh, Cambodia \\ ${ }^{5}$ Center of Excellence on Sustainable Agricultural Intensification and Nutrition, Royal University of Agriculture, Phnom Penh, \\ Cambodia \\ Email: *samonsreng@gmail.com
}

How to cite this paper: Sreng, S., Keo, S., DeRouchey, J.M., Tokach, M.D., Hok, L. and Vipham, J.L. (2020) Effect of Complete Feed Feeding Level and Morning Glory on Growing Pig Performance. Open Journal of Animal Sciences, 10, 493-501.

https://doi.org/10.4236/ojas.2020.103030

Received: May 23, 2019

Accepted: June 21, 2020

Published: June 24, 2020

Copyright (c) 2020 by author(s) and Scientific Research Publishing Inc. This work is licensed under the Creative Commons Attribution International License (CC BY 4.0).

http://creativecommons.org/licenses/by/4.0/

\begin{abstract}
A total of 60 castrated male pigs (Yorkshire $\mathrm{x}$ Duroc, initially $17.36 \mathrm{~kg}$ ) were used in a 42-day trial to evaluate the effect of complete feed feeding level and morning glory on growth performance of growing pigs. Pigs were allotted to pens and randomly assigned to three dietary treatments: A) completed feed fed ad libitum; B) complete feed fed at $75 \%$ of intake of treatment A, and C) treatment $\mathrm{B}$ with ad libitum availability of morning glory. The design was a completely randomized design (CRD) with five pens (replications) of each treatment with four pigs per pen. Average daily feed intake (dry matter basis) was higher $(P<0.001)$ for pigs fed treatment A $(1420 \mathrm{~g} / \mathrm{d})$ compared to treatment B $(1048 \mathrm{~g} / \mathrm{d})$ as expected, with treatment C intermediate $(1178 \mathrm{~g} / \mathrm{d}$; $1048 \mathrm{~g} / \mathrm{d}$ complete feed $+130 \mathrm{~g} / \mathrm{d}$ morning glory). Average daily weight gain of pigs fed ad libitum was greater $(P<0.001)$ than pigs restricted fed with pigs which provide morning glory intermediate $(871,674$ and $714 \mathrm{~g}$, respectively). Feed efficiency improved $(P<0.024)$ for pigs fed the restricted feed level compared to pigs fed complete feed ad libitum or pigs restricted fed but provided morning glory (1.63, 1.56 and 1.65 , respectively). For economics, feeding complete feed ad libitum improved $(P<0.001)$ income over feed cost compared to restricted feeding or providing morning glory (USD 41.48, 33.42 , and $33.89 / \mathrm{pig}$, respectively). In conclusion, feeding growing pigs a complete diet ad libitum resulted in the greatest growth rate and profitability. Offering morning glory (Ipomoea. aquatica) to pigs fed a restricted level of complete feed did improve final body weight, but the extra cost of feeding morning glory offset this advantage resulting in similar profitability on an income over feed cost basis.
\end{abstract}




\section{Keywords}

Complete Feed, Feed Restriction, Growing Pig, Growth Performance, Morning Glory

\section{Introduction}

In countries with a lack of a sufficient domestic commercial swine feed and low utilization of alternative domestic feed resources, a higher cost of production is found [1]. Since feed cost is the most expensive input in commercial pig production [2], pig diet formulation and feeding strategies are not only important for animal performance, but also to maximize profitability [3]. Cambodia imported an increasingly amount of commercial feed from 60,000 tons in 2009 to 452,671 tons in 2013 to fulfill the requirement of the growing feed need [4].

A restricted feeding program where pigs are fed less than ad libitum intake will reduce overall growth performance and bone growth and mineralization in growing pigs [5]. While medium and larger producers of swine often feed complete rations ad libitum, due to the high cost of purchased feed, small scale producers do not. In order to have more economical rations for swine, small farms in Cambodia often feed rice bran, kitchen waste, or other locally available feed ingredients [6]. For instance, water morning glory or spinach (Ipomoea aquatic), which is marsh plant, is readily grown in Cambodia and other South-East Asian regions allowing it to be widely used for feeding pigs [7]. However, morning glory is a fibrous plant that offers little nutritional value to swine since it is fed fresh after harvest, thus having low dry matter content.

\section{Material and Methods}

\subsection{The Site of Study and Climate Condition}

The experiment was conducted at local pig barn facility in the district of S'ang, Kandal province, approximately $21 \mathrm{~km}$ from Phnom Penh, Cambodia. The regional climate during the study was in rainy season (May to October) with the average daily temperature of $29^{\circ} \mathrm{C}$ with $81 \%$ humidity. Daily temperature and humidity were measured inside the pig barn. Minimum and maximum temperatures were $25^{\circ} \mathrm{C}$ and $37^{\circ} \mathrm{C}$, respectively, and relative humidity was ranged from $74 \%$ to $91 \%$ during the experiment.

\subsection{Pigs and Experimental Design}

A total of 60 castrate male pigs (Yorkshire x Duroc) were purchased from a large commercial farm with an initial body weight of $17.36 \mathrm{~kg}$ was used in a 42-day trial. Pigs were allotted to pens and randomly assigned to three dietary treatments: A) completed feed fed ad libitum; B) complete feed fed at $75 \%$ of intake of treatment $\mathrm{A}$, and C) complete feed fed at $75 \%$ of intake of treatment $\mathrm{A}$ with ad libitum availability of morning glory. The $75 \%$ of intake level was chosen as 
this was a routine amount given by small swine producers in Cambodia. The experiment was a completely randomized design (CRD) with five pens (replications) of each treatment and four pigs per pen. Pigs were put into individual pens $(2 \times 3 \mathrm{~m})$ with concrete floor. A nipple drinker was available in each pen to provide ad libitum access to fresh water. Pigs had been adapted to the barn and environment for 7 days prior to the start of the experiment which was conducted from May 9 to June 22, 2018.

\subsection{Diets and Feeding}

Complete feed was formulated to two dietary phases (Table 1) based on the nutrient requirements of pigs from 17 to $30 \mathrm{~kg}$ and 30 to $50 \mathrm{~kg}$ body weight, respectively. For the two phases, the complete feeds had a crude protein content of $19 \%$ and $16 \%$ with metabolizable energy of 3350 and $3300 \mathrm{kcal} / \mathrm{kg}$, respectively (manufactured by CP Cambodia co. Ltd). The complete feed was in pellet form. Fresh morning glory was harvested and purchased from a local supplier. Morning glory (Ipomoea aquatica) was cleaned with fresh water and chopped into a small piece prior to provide to pigs daily. In treatment $\mathrm{A}$, complete feed was offered

Table 1. Composition of complete diets used in the experiment (as-fed basis) a

\begin{tabular}{ccc}
\hline Items, \% & Diet 1 & Diet 2 \\
\hline Corn & 40.00 & 40.00 \\
Cassava & - & 11.00 \\
Wheat & 15.00 & - \\
Full Fat Soy & 6.50 & - \\
Soybean meal & 21.00 & 27.00 \\
Rice bran full fat & - & 15.00 \\
Palm Oil & 4.00 & 4.00 \\
Milk Product & 5.00 & - \\
Other & 8.40 & 2.90 \\
Vitamin Premix & 0.05 & 0.04 \\
Mineral Premix & 0.06 & 0.06 \\
Calculated Nutrition & & 16.00 \\
ME, kcal/kg & 3350 & 4.00 \\
Crude protein, \% & 19.00 & 4.00 \\
Fat, \% & 4.00 & 0.66 \\
Crude fiber, \% & 4.00 & 0.32 \\
Calcium, \% & 0.70 & 1.00 \\
Phosphorus, \% & 0.38 & \\
SID Lysine, \% & 1.25 & \\
\hline & & \\
\hline
\end{tabular}

aiet $1 \mathrm{fed}$ from approximately 17 to $30 \mathrm{~kg}$ body weight and diet 2 from approximately 30 to $50 \mathrm{~kg}$ body weight. Diets were fed in pellet form and manufactured by CP Cambodia Co. Ltd. ${ }^{\mathrm{b}}$ Minerals, synthetic amino acids, and other proprietary ingredients. 
ad libitum to pigs and the amount of daily feed consumption of pigs in this treatment was measured to set the feeding level of complete feed for treatments B and C. Actual feed intake achieved was $74 \%$ for both treatments B and C compared to pigs fed at ad libitum. Pigs were fed three times a day at 07:00, 12:00 and 18:00. For economics, the complete diet cost for phase 1 complete feed was USD $0.60 / \mathrm{kg}$, phase 2 complete feed was USD $0.50 / \mathrm{kg}$ and morning glory was USD $0.06 / \mathrm{kg}$ fresh. Also, a value of USD $2.125 / \mathrm{kg}$ was used to calculate the revenue value of weight gain during the experiment.

\subsection{Sample and Data Collection}

Any residual feed not consumed by each pen of pigs was weighed back and recorded daily. Morning glory and complete feed samples were collected, sent to Chemical Analysis Laboratory, Royal University of Agriculture, Phnom Penh, and analyzed for dry matter in order to calculate feed intake on a dry matter basis. Pigs were individually weighed on $\mathrm{d} 0,7,14,21,28$ and 42 day of the study to calculate ADG, ADFI and feed efficiency (F/G).

\subsection{Analytical Analysis}

Complete feed and fresh morning glory samples were collected and analyzed for dry matter according to the official method [8] (Code 934.01). Ash was ignited in a muffle furnace at $600^{\circ} \mathrm{C}$ during $2 \mathrm{~h}$ according to the description of [8] (Code 942.05). Crude protein was determined by Leco FP-528 (LECO Corporation, ISO-9001:2008, USA, 2014), and estimated a calculation of crude protein factor ( $\mathrm{N} x$ 6.25). Ether Extract (EE) was determined by using ST243 SoxtecTM Extraction Unit (Foss Analytical Co., Ltd, China, 2014). Neutral Detergent Fiber (NDF), Acid Detergent Fiber (ADF), and Crude Fiber were determined by ANKOM 200i, approved procedure by AOCS (ANKOM Technology, USA).

\subsection{Statistical Analysis}

All data were entered and prepared to statistical analysis in Microsoft excel 2013. Statistical analysis was conducted by using the software of Statistical Package for the Social Sciences (SPSS) version 18.0. The analytical procedure was processed with one-way of analysis of variance (ANOVA-test) to compare the variable means, and determined the statistical significant different of means at the probability level $(P<0.05)$. Duncan test was used to evaluate the difference between means.

\section{Results}

The chemical composition of morning glory (Ipomoea aquatica) showed low DM (10.38\%) and EE (2.43\%) concentrations but higher CP (25.35\%) on a DM basis (Table 2). The ash, crude fiber, ADF, and NDF concentrations were relatively high as expected. The DM content of Diet 1 was $87.58 \%$ while than Diet 2 was $89.64 \%$. The CP analysis of complete feed for Diet 1 and Diet 2 were similar 
Table 2. Chemical composition of complete feed and morning glory used for the experiment $\left(\%\right.$ as DM) ${ }^{\mathrm{a}}$.

\begin{tabular}{cccc}
\hline Items & Diet 1 & Diet 2 & Morning glory \\
\hline Dry matter & 87.58 & 89.64 & 10.38 \\
Crude protein & 19.64 & 16.81 & 25.35 \\
Crude fiber & 3.61 & 2.57 & 14.94 \\
Ether extract & 6.85 & 6.48 & 2.43 \\
Ash & 5.08 & 5.29 & 12.58 \\
Acid detergent fiber & 4.70 & 3.85 & 24.76 \\
Neutral detergent fiber & 9.05 & 7.82 & 26.17 \\
\hline
\end{tabular}

${ }^{\text {aDiet }} 1$ fed from approximately 17 to $30 \mathrm{~kg}$ body weight and diet 2 from approximately 30 to $50 \mathrm{~kg}$ body weight.

to calculated values. The ether extract of both diets were higher than expected, but the crude fiber was lower.

Pig growth performance during phase 1 ( $\mathrm{d} 0$ to 21 ), body weight, ADG, and ADFI were greater $(P<0.001)$ for pigs fed ad libitum compared to pigs on both other treatment diets (Table 3). Also, pigs fed the restricted level of complete diet with morning glory had improved body weight, ADG, and ADFI compared to pigs fed on the restricted diet. For feed efficiency, pigs fed the restricted level of complete diet had improved $(P<0.024) \mathrm{F} / \mathrm{G}$ compared to both other treatments.

For phase 2 (d 21 to 42 ), ADG was improved $(P<0.001)$ for pigs fed ad libitum compared to pigs fed both other treatments. Pigs fed ad libitum had greater $(P<0.001)$ ADFI than pigs fed both other treatments, while those fed the restricted complete diet with morning glory had increased $(P<0.001)$ feed intake compared to those only receiving the restricted diet. There was no significant $(P>0.063)$ difference in $\mathrm{F} / \mathrm{G}$ between treatments.

For the overall study (d 0 to 42 ), ADG and final body weight were greater $(P<$ 0.001 ) for pigs fed ad libitum compared to both other treatments, while restricted fed pigs provided with morning glory had greater $(P<0.001)$ ADG and body weight then pigs fed the restricted diet without morning glory. For ADFI, pigs fed ad libitum had increased $(P<0.001)$ intake compared to both other treatments with pigs fed the restricted complete diet with morning glory being intermediate. Feed efficiency improved $(P<0.024)$ for restricted fed pigs compared both other treatments. For economics, feeding pigs the complete feed ad libitum increased $(P<0.001)$ feed cost per pig and gain value compared with the other two treatments with pigs fed the restricted diet with morning glory intermediate for both measurements. For income over feed cost, pigs fed the complete feed ad libitum had increased $(P<0.001)$ return compared to restrict feeding or restricted feeding with morning glory.

\section{Discussion}

The DM content of morning glory was an agreement with previous results [9] 
Table 3. Effect of complete feed feeding level and morning glory (Ipomoea aquatica) on growing pig performance ${ }^{\mathrm{d}}$.

\begin{tabular}{|c|c|c|c|c|c|}
\hline \multirow[b]{2}{*}{ Items } & \multicolumn{3}{|c|}{ Diets Fed } & \multirow[b]{2}{*}{ SEM } & \multirow[b]{2}{*}{$P<$} \\
\hline & ad libitum & $75 \%$ ad libitum & $\begin{array}{l}75 \% \text { ad libitum } \\
+ \text { Morning glory }\end{array}$ & & \\
\hline \multicolumn{6}{|c|}{ Body weight, kg } \\
\hline D 0 & 17.35 & 17.36 & 17.37 & 0.011 & 0.755 \\
\hline D 21 & $33.13^{\mathrm{a}}$ & $29.50^{c}$ & $30.40^{\mathrm{b}}$ & 0.424 & 0.001 \\
\hline D 42 & $53.92^{\mathrm{a}}$ & $45.66^{\mathrm{c}}$ & $47.38^{\mathrm{b}}$ & 0.972 & 0.001 \\
\hline \multicolumn{6}{|l|}{ Day 0 to 21} \\
\hline ADG, $g$ & $751^{\mathrm{a}}$ & $578^{\mathrm{c}}$ & $620^{\mathrm{b}}$ & 20.29 & 0.001 \\
\hline ADFI, $g$ & $1,105^{\mathrm{a}}$ & $806^{c}$ & $922^{\mathrm{b}}$ & 33.42 & 0.001 \\
\hline $\mathrm{F} / \mathrm{G}$ & $1.47^{\mathrm{a}}$ & $1.40^{\mathrm{b}}$ & $1.49^{\mathrm{a}}$ & 0.015 & 0.024 \\
\hline \multicolumn{6}{|l|}{ Day 21 to 42} \\
\hline ADG, $g$ & $990^{\mathrm{a}}$ & $770^{\mathrm{b}}$ & $809^{\mathrm{b}}$ & 26.99 & 0.001 \\
\hline ADFI, g & $1734^{\mathrm{a}}$ & $1291^{\mathrm{c}}$ & $1434^{\mathrm{b}}$ & 54.17 & 0.001 \\
\hline $\mathrm{F} / \mathrm{G}$ & 1.75 & 1.68 & 1.77 & 0.017 & 0.063 \\
\hline \multicolumn{6}{|l|}{ Day 0 to 42} \\
\hline ADG, $g$ & $871^{\mathrm{a}}$ & $674^{\mathrm{c}}$ & $714^{\mathrm{b}}$ & 23.19 & 0.001 \\
\hline ADFI, $g$ & $1420^{\mathrm{a}}$ & $1048^{\mathrm{c}}$ & $1178^{\mathrm{b}}$ & 43.03 & 0.001 \\
\hline $\mathrm{F} / \mathrm{G}$ & $1.63^{\mathrm{a}}$ & $1.56^{\mathrm{b}}$ & $1.65^{\mathrm{a}}$ & 0.015 & 0.024 \\
\hline \multicolumn{6}{|c|}{ Economics, USD/pig } \\
\hline Feed cost ${ }^{\mathrm{e}}$ & $36.21^{\mathrm{a}}$ & $26.72^{c}$ & $29.87^{b}$ & 1.09 & 0.001 \\
\hline Gain value $^{\mathrm{f}}$ & $77.70^{\mathrm{a}}$ & $60.14^{\mathrm{c}}$ & $63.76^{\mathrm{b}}$ & 2.07 & 0.001 \\
\hline $\mathrm{IOFC}^{\mathrm{g}}$ & $41.49^{\mathrm{a}}$ & $33.42^{\mathrm{b}}$ & $33.89^{\mathrm{b}}$ & 1.03 & 0.001 \\
\hline
\end{tabular}

a,b,c Different superscripts are significantly different, $P<0.05$. d. A total of 60 pigs (initially $17.36 \mathrm{~kg} / \mathrm{body}$ weight) was used in a 42 days studying with 4 pigs per pen and 5 pens per treatment. ${ }^{\mathrm{e}}$ Assuming in complete feed phase 1 diet ( $\mathrm{d} 0$ to 21$)=\$ 0.60 / \mathrm{kg}$; complete feed phase 2 diet ( $\mathrm{d} 21$ to 42$)=\$ 0.50 / \mathrm{kg}$, and morning glory $\$ 0.06 / \mathrm{kg}$ fresh. ${ }^{\mathrm{f}}$ Assuming a pig price of $\$ 2.125 / \mathrm{kg}$ for body weight gain from $\mathrm{d} 0$ to 42 ). ${ }^{\text {g Income }}$ over feed cost $($ IOFC $)=$ gain value - feed cost.

[10] [11], which showed a range from $9.1 \%$ to $11.2 \%$, respectively. The CP content of morning glory in the present study was similar to other published values [9] [11] [12], ranging from $18.8 \%$ to $25.6 \%$. Moreover, the ash content was $12.58 \%$, which agreed with data from [12]; but being lower than results of [9]. Likewise, the crude fiber content was $14.94 \%$, which showed lower value than $22.80 \%$ CF result reported by [9]. Ether extract, ADF, and NDF contents were $2.43 \%, 24.76 \%$ and $26.17 \%$ which were lower than published by [12].

Due to the higher cost of complete feed, small swine producers that do purchase this type of feed often do not offer it ad libitum. As expected in our study, pigs fed at $75 \%$ ad libitum had reduced growth rate than pigs fed ad libitum. This finding is in agreement with [5] [13] [14]. According to [5], when pigs were 
fed to $70 \%$ of ad libitum feed intake, pigs grew $41 \%$ slower, meanwhile, in our study pigs that consumed at $75 \%$ ad libitum grew $23 \%$ slower and only $18 \%$ less when also offered morning glory. Lovatto [14] reported that when pigs are fed a restricted level of feed intake, they had lower protein and lipid gain which would support the lower body weight gain reported in our study. Weremko [5] reported that young pigs subjected to short-term deficiency of protein and energy intake for 28 days were able to recover and even surpass the parameters of bone mineralization compared with adequately fed pigs during those same 28 days when subsequently placed on nutrient adequate diets for approximately 50 days. When restricting the amount of feed per day to growing pigs, [15] reported that pigs offered the feed 6 vs. 2 times per day had improved ADG and feed efficiency. This is an important finding in this area of research to show how providing the same level of daily nutrients multiple times per day can potentially improve nutrient utilization and have less feed wastage compared to providing larger, less frequent meals. In the current study, pigs were offered feed three times per day.

Morning glory is a forage that is readily grown in many areas in Asia and is used for human food and as a feedstuff for livestock. As a typical forage, it is low in dry matter and fat, while high in fiber. Although not an ideal feedstuff for monogastrics compared to ruminant animals, it can be harvested daily and offered fresh to swine. In our study, the pigs fed a restricted level of complete feed did consume morning glory when it was chopped and offered ad libitum resulting in a significantly increased daily feed intake over the 42-day study. Chhay Ty [7] pigs fed morning glory or cassava leaves mixed with rice bran and reported pigs consumed greater amounts of mixed feed containing morning glory. This data along with the present study shows that the palatability of morning glory for pigs is acceptable and does not decrease their daily feed intake.

It should be noted that of the chopped morning glory offered pigs in our study, it was visually observed that more leaves and less stems were consumed daily. Samkol [16] reported that morning glory leaves contained a DM content of $\sim 10 \%$ and also a higher crude protein concentration (35.1\% DM basis) compared to the stem which had lower CP concentration (20.5\% DM basis). This may explain why pigs offered the morning glory had intermediate performance compared to the other two treatments. While morning glory is lower in energy content than complete feed, pigs did utilize enough of the nutrients consumed to improve body weight compared to pigs not offered morning glory.

Economic evaluations have not been conducted in previous research evaluating feed restriction or feeding morning glory. While feed cost per pig increases with feeding complete feed ad libitum, the value of the extra body weight gain also increases resulting in the highest margin over feed cost, or a measure of net profitability. While pigs offered morning glory had increased revenue compared to those fed the restricted feeding level alone, the added feed cost of morning glory offset this advantage and resulted in not being more profitable. Thus, a swine producer must purchase morning glory at a lower cost or harvest it on their own land to justify its use in growing swine diets. 


\section{Conclusion}

Feeding growing pigs a complete diet ad libitum resulted in the greatest growth rate and profitability. However, feeding a restriction of daily feed intake at $75 \%$ can improve feed efficiency compared to ad libitum fed pigs. Finally, offering morning glory (Ipomoea aquatica) to pigs fed a restricted level of complete feed did improve final body weight, but the extra cost of feeding morning glory offset this advantage resulting in similar profitability on an income over feed cost basis.

\section{Acknowledgements}

This work was funded in whole or part by the United States Agency for International Development (USAID) Bureau for Food Security under Agreements \# AID-EEP-A-00-09-00004 and AID-OAA-L-15-00003 as part of Feed the Future Innovation Lab for Horticulture and Feed the Future Innovation Lab for Livestock Systems.

\section{Conflicts of Interest}

The authors declare no conflicts of interest regarding the publication of this paper.

\section{References}

[1] Food and Agriculture Organization (2008) Swine Marketing in Cambodia: Reducing Market Distortion, Improving Competitiveness and Ensuring Safe Trade. 7-8.

[2] Velayudhan, D.E., Kim, I.H. and Nyachoti, C.M. (2015) Characterization of Dietary Energy in Swine Feed and Feed Ingredients: A Review of Recent Research Results. Asian-Australian Journal of Animal Sciences, 28, 1-13. https://doi.org/10.5713/ajas.14.0001R

[3] Chiba, L.I. (2000) Feeding Systems for Pigs. In: Theodorou, M.K. and France, J., Eds., Feeding Systems and Feed Evaluation Models, CABI Publishing, Wallingford, 181-183.

[4] Ministry of Agriculture, Forestry and Fisheries (MAFF) (2015) Strategic Planning Framework for Livestock Development: 2016-2025: “A Future Direction for Livestock Development in Cambodia". 4-5.

[5] Weremko, D., Skiba, G., Raj, St. and Fandrejewski, H. (2013) The Effects of Feed and Protein Restriction between 90 and 118 Days of Age on Performance, Bone Growth and Mineralization of Pigs Reared to 168 Days of Age. Animal Feed Science and Technology, 182, 53-60. https://doi.org/10.1016/j.anifeedsci.2013.04.004

[6] Samkol, P., Borin, K. and Sovann, S. (2006) Pig Systems in Southeast Asia-The Case of Cambodia. Proceedings of Pig Systems in Asia and the Pacific. How Can Research and Development Enhance Benefits to the Poor, Bangkok, 23-24 November 2006, 34. http://cdn.dairyasia.org/APHCA/dmdocuments/PAP 06 Asia Pig Systems Ws.pd $\underline{\mathrm{f}}$

[7] Chhay, T., Borin, K. and Preston, T.R. (2007) Effect of Mixtures of Water Spinach and Fresh Water Hyacinth Leaves on Growth Performance of Pigs Feed a Basal Diet of Rice Bran and Cassava Root Meal. Livestock Research for Rural Development, 
19, Article \#194. http://www.lrrd.org/lrrd19/12/chha19194.htm

[8] AOAC (1990) Official Methods of Analysis. 15th Edition, Association of Official Analysis Chemists, Arlington.

[9] Phiny, C., Ogle, B.M., Preston, T.R. and Borin, K. (2008) Growth Performance of Pigs Fed Water Spinach or Water Spinach Mixed with Mulberry Leaves, as Protein Sources in Basal Diets of Cassava Root Meal plus Rice Bran or Sugar Palm Syrup plus Broken Rice. Livestock Research for Rural Development, 20. http://www.lrrd.org/lrrd20/supplement/phin2.htm

[10] Ogle, B.M., Ha Thi Anh Dao and Generose, M.B. (2001) Micronutrient Composition and Nutritional Importance of Gathered Vegetables in Vietnam. International Journal of Food Sciences and Nutrition, 52, 485-499.

https://doi.org/10.1080/713671806

[11] Chhay, T. and Preston, T.R. (2005) Effect of Water Spinach and Fresh Cassava Leaves on Growth Performance of Pigs Fed a Basal Diet of Broken Rice. Livestock Research for Rural Development, 17, Article 76. http://www.lrrd.org/lrrd17/7/chha17076.htm

[12] Supharoek, N., Mikled, C. and Ledin, I. (2008) Effect Off Feeding Head Lettuce, Water Spinach, Ruzi Grass or Mimosa Pigra on Feed Intake, Digestibility and Growth in Rabbits. Asian-Australian Journal of Animal Sciences, 21, 1171-1177. https://doi.org/10.5713/ajas.2008.70628

[13] Daza, A., Rodriguez, I., Ovejero, I. and López-Bote, C. (2003) Effect on Pig Performance of Feed Restriction during the Growth Period. Spanish Journal of Agricultural Research, 1, 3-8. https://doi.org/10.5424/sjar/2003014-42

[14] Lovatto, P.A., Sauvant, D., Noblet, J., Dubois, S. and van Milgen, J. (2006) Effects of Feed Restriction and Subsequent Refeeding on Energy Utilization in Growing Pigs. Journal of Animal Science, 84, 3329-3336. https://doi.org/10.2527/jas.2006-048

[15] Schneider, J.D., Tokach, M.D., Goodband, R.D., Nelssen, J.L., Dritz, S.S., DeRouchey, J.M. and Sulabo, R.C. (2011) Effects of Restricted Feed Intake on Finishing Pigs Weighing between 68 and 114 Kilograms Fed Twice or 6 Times Daily. Journal of Animal Science, 89, 3326-3333. https://doi.org/10.2527/jas.2010-3154

[16] Samkol, P., Preston, T.R. and Ly, J. (2006b) Digestibility Indices and N Balance in Growing Rabbits Fed a Basal Diet of Water Spinach (Ipomoea aquatica) Supplemented with Broken Rice. Livestock Research for Rural Development, 18. http://www.lrrd.org/lrrd18/2/samk18022.htm 